\title{
New Year's greetings 2020 from the Journal of Plant Research
}

\author{
Kouki Hikosaka ${ }^{1}$
}

Published online: 2 January 2020

(c) The Botanical Society of Japan and Springer Japan KK, part of Springer Nature 2019

Last year, we published two JPR symposium issues: "Regulatory networks in plant growth and development" under the supervision of Drs. Kengo Morohashi and Eugenia Russinova (Morohashi and Russinova 2019; March issue) and "Toward unveiling plant adaptation mechanisms to environmental stresses" under the supervision of Drs. Michitaro Shibata and Junro Mogami (Shibata and Mogami 2019; May issue). The first symposium, "Regulatory networks in plant growth and development", collected papers on gene regulatory networks in various phenomena of plant growth and development; i.e., cell expansion (Ilias et al. 2019), secondary metabolisms (Shoji and Hashimoto 2019, Jamaluddin et al. 2019), and morphological development (Arai et al. 2019). The second symposium, "Toward unveiling plant adaptation mechanisms to environmental stresses", collected two review articles on environmental signals for root development (Shibata and Sugimoto 2019) and on water transport, perception, and response in plants (Scharwies and Dinneny 2019).

We also published a virtual issue, "Ecology and evolution of pteridophytes in the era of molecular genetics", edited by Drs. Joel H. Nitta and A. Ebihara (Nitta and Ebihara 2019), on the website of the Journal of Plant Research (https:// www.springer.com/journal/10265/updates/17220618). The past quarter-century has witnessed a revolution in our understanding of the phylogenetics, systematics, and ecology of pteridophytes (ferns and lycophytes), particularly due to the rapid accumulation of plastid sequence data and a renewed interest in the ecology of the sexual phase of the life cycle. This virtual issue contains 19 articles published after 2009 in the Journal of Plant Research (Chang et al. 2018; Chen et al. 2018; Ebihara and Nitta 2019; Ebihara et al. 2012; Fujiwara et al. 2018; Hori et al. 2014; Kessler and Lehnert 2009; Kuo et al. 2017; Lu et al. 2012; Nakato et al. 2012; Naugolnykh et al.2016; Ogura-Tsujita et al. 2013; 2019; Ootsuki et al.

Kouki Hikosaka

hikosaka@tohoku.ac.jp

1 Graduate School of Life Sciences, Tohoku University, Sendai, Japan
2012; Tian et al. 2014; Yatabe et al. 2009; Yatabe-Kakugawa et al. 2013; Wang et al. 2015; Winther and Friedman 2009).

We welcome new Editors and Editorial Board members who begin their 4-year term in January 2020: Drs. Juan Núñez-Farfán, Akitoshi Iwamoto, Ali Ferjani, Kimitsune Ishizaki, Jutta Papenbrock, Shigemi Seo, and Michael Wrzaczek (Editor) and Drs. José Gutiérrez-Ortega, Qingxiang Han, Hossein Kazemi, Tianxiang Luo, Riichi Oguchi, Yoshihiro Suzuki, Kester Bull-Hereñu, Hirofumi Nakagami, Hokuto Nakayama, Satoko Yoshida, Jeffery Cruz, Toshiyuki Fukuhara, Atsushi Takeda, and Takumi Higaki (Editorial Board members).

We thank the Editors and Editorial Board members who rotate off: Drs. Eric DeChaine, Thomas Berberich, and Kintake Sonoike (Editor) and Drs. Steffi Ickert-Bond, Steven Manchester, Fernand Valladares, Wan-Jin Liao, Ülo Niinemets, Naoyuki Uchida, Gerrit Beemster, Misako Kato, Natsumaro Kutsuna, Toshio Sakamoto, Keiko Yoshioka, KuoChen Yeh, Bhasker Gupta (Editorial Board members). Drs. Ichirou Karahara and Tomoaki Nishiyama also finished their terms as Editors, but rejoin us as Editorial Board members.

We have revised our Instructions to Authors (https:// www.springer.com/journal/10265/submission-guidelines). Importantly, from 2020, we no longer impose page charges on authors irrespective of whether the authors are members of the Botanical Society of Japan. Page limitations have also been removed except for Technical notes and Letters. We welcome submissions of articles regardless of their length (however, the editor may require a paper to be shortened if it is considered unnecessarily long). We also clarify our scope on submitted papers: we will accept papers that contribute to general basic plant sciences. Papers targeted toward applied science such as agricultural or medical research may be rejected without review if they do not make significant contributions to general plant sciences.

We wish you a Very Happy New Year, and we welcome submissions of excellent articles in 2020.

Kouki Hikosaka

Editor-in-Chief, Journal of Plant Research 


\section{References}

Arai H, Yanagiura K, Toyama Y, Morohashi K (2019) Genome-wide analysis of MpBHLH12, a IIIf basic helix-loop-helix transcription factor of Marchantia polymorpha. J Plant Res 132:197-209

Chang Y, Ebihara A, Lu S, Liu H, Schneider H (2018) Integrated taxonomy of the Asplenium normale complex (Aspleniaceae) in China and adjacent areas. J Plant Res 131:573-587

Chen CW, Rothfels CJ, Mustapeng AMA, Gubilil M, Karger DN, Kessler M, Huang YM (2018) End of an enigma: Aenigmopteris belongs in Tectaria (Tectariaceae: Polypodiopsida). J Plant Res 131:67-76

Ebihara A, Nitta JH (2019) An update and reassessment of fern and lycophyte diversity data in the Japanese archipelago. J Plant Res 132:723-738

Ebihara A, Matsumoto S, Kato M (2012) Origin of Dryopteris shibipedis (Dryopteridaceae), a fern species extinct in the wild. J Plant Res 125:499-505

Fujiwara T, Serizawa S, Watano Y (2018) Phylogenetic analysis reveals the origins of tetraploid and hexaploid species in the Japanese Lepisorus thunbergianus (Polypodiaceae) complex. J Plant Res 131:945-959

Hori K, Tono A, Fujimoto K, Kato J, Ebihara A, Watano Y, Murakami N (2014) Reticulate evolution in the apogamous Dryopteris varia complex (Dryopteridaceae, subg. Erythrovariae, sect. Variae) and its related sexual species in Japan. J Plant Res 127:661-684

Ilias IA, Negishi K, Yasue K, Jomura N, Morohashi K, Baharum SN, Goh H-H (2019) Transcriptome-wide effects of expansin gene manipulation in etiolated Arabidopsis seedling. J Plant Res 132:159-172

Jamaluddin ND, Rohani ER, Noor NM, Goh H-H (2019) Transcriptome-wide effect of DE-ETIOLATED1 (DET1) suppression in embryogenic callus of Carica papaya. J Plant Res 132:181-195

Kessler M, Lehnert M (2009) Do ridge habitats contribute to pteridophyte diversity in tropical montane forests? A case study from southeastern Ecuador. J Plant Res 122:421-428

Kuo LY, Chen CW, Shinohara W, Ebihara A, Kudoh H, Sato H, Huang YM, Chiou WL (2017) Not only in the temperate zone: independent gametophytes of two vittarioid ferns (Pteridaceae, Polypodiales) in East Asian subtropics. J Plant Res 130:255-262

Lu JM, Wen J, Lutz S, Wang YP, Li DZ (2012) Phylogenetic relationships of Chinese Adiantum based on five plastid markers. J Plant Res 125:237-249

Morohashi K, Russinova E (2019) Towards a next step of the research of regulatory networks in plant growth and development. J Plant Res 132:155-157

Nakato N, Ootsuki R, Murakami N, Masuyama S (2012) Two types of partial fertility in a diploid population of the fern Thelypteris decursive-pinnata (Thelypteridaceae). J Plant Res 125:465-474
Naugolnykh SV, Wang L, Han M, Jin JH (2016) A new find of the fossil Cyclosorus from the Eocene of South China and its paleoclimatic implication. J Plant Res 129:3-12

Nitta JH, Ebihara A (2019) Virtual issue: ecology and evolution of pteridophytes in the era of molecular genetics. J Plant Res 132:719-721

Ogura-Tsujita Y, Sakoda A, Ebihara A, Yukawa T, Imaichi R (2013) Arbuscular mycorrhiza formation in cordate gametophytes of two ferns, Angiopteris lygodiifolia and Osmunda japonica. J Plant Res 126:41-50

Ogura-Tsujita Y, Yamamoto K, Ebihara A, Morita N, Imaichi R (2019) Fern gametophytes of Angiopteris lygodiifolia and Osmunda japonica harbor diverse Mucoromycotina fungi. J Plant Res 132:581-588

Ootsuki R, Sato H, Nakato N, Murakami N (2012) Evidence of genetic segregation in the apogamous fern species Cyrtomium fortunei (Dryopteridaceae). J Plant Res 125:605-612

Scharwies J, Dinneny JR (2019) Water transport, perception, and response in plants. J Plant Res 132:311-324

Shibata M, Mogami J (2019) Toward a multifaceted understanding of plants' adaptation mechanisms. J Plant Res 132:299

Shibata M, Sugimoto K (2019) A gene regulatory network for root hair development. J Plant Res 132:301-309

Shoji T, Hashimoto T (2019) Expression of a tobacco nicotine biosynthesis gene depends on the JRE4 transcription factor in heterogenous tomato. J Plant Res 132:173-180

Tian N, Wang YD, Philippe M, Zhang W, Jiang ZK, Li LQ (2014) A specialized new species of Ashicaulis (Osmundaceae, Filicales) from the Jurassic of Liaoning, NE China. J Plant Res 127:209-219

Wang Y, Li L, Guignard G, Dilcher DL, Xie X, Tian N, Zhou N, Wang $Y(2015)$ Fertile structures with in situ spores of a dipterid fern from the Triassic in Southern China. J Plant Res 128:445-457

Winther JL, Friedman WE (2009) Phylogenetic affinity of arbuscular mycorrhizal symbionts in Psilotum nudum. J Plant Res 122:485-496

Yatabe Y, Tsutsumi C, Hirayama Y, Mori K, Murakami N, Kato M (2009) Genetic population structure of Osmunda japonica, rheophilous Osmunda lancea and their hybrids. J Plant Res 122:585-595

Yatabe-Kakugawa Y, Tsutsumi C, Hirayama Y, Tsuneki S, Murakami N, Kato M (2013) Transmission ratio distortion of molecular markers in a doubled haploid population originated from a natural hybrid between Osmunda japonica and $O$. lancea. J Plant Res 126:469-482

Publisher's Note Springer Nature remains neutral with regard to jurisdictional claims in published maps and institutional affiliations. 